\title{
Large-scale structure of the eclogite-blueschist belt of New Caledonia
}

\author{
Timothy J. Rawling, Gordon S. Lister* \\ Australian Crustal Research Centre, Department of Earth Sciences, Monash University, Melbourne, Victoria 3800, Australia
}

Received 5 August 1999; revised 5 September 2001; accepted 14 September 2001

\begin{abstract}
This paper considers the large-scale geometry of the northern part of the eclogite-blueschist belt of New Caledonia, based largely on classical-style structural analysis, but in consideration of modern concepts regarding crustal extension, exhumation of high-pressure rocks and uplift. Shear zones played an important role in the evolution of the region. Early shear zones and high pressure metamorphism appear to be associated with overthrusting of an ultramafic sheet. Middle-stage shear zones are associated with large-scale continental extension, during which the high-pressure rocks were exhumed. The extended crust was subsequently folded during renewed compression, producing an orogen-scale antiform throughout the high-pressure belt that folds all previously formed structures. Late stage shear zones formed when the orogen was once again thrown into extension. Relatively youthful normal faults caused late block-faulting, uplifting a regional peneplain and producing the present geomorphology.

Previously published interpretations of the structure and geometry of the belt have suggested that the high-pressure rocks are found in the core of a regionally developed antiform, interpreted as a metamorphic core complex. Our structural mapping shows that allochthonous slices of high-pressure rocks are draped over a younger (unrelated) foliation antiform. Lower-grade (retrogressed equivalent) rocks are found within the core of the antiform. Thus the metamorphic core complex model is rejected. (C) 2002 Elsevier Science Ltd. All rights reserved.

Keywords: Eclogite-blueschist belt; Crustal extension; Shear zones; New Caledonia
\end{abstract}

\section{Introduction}

The high-pressure rocks of northeast New Caledonia (Fig. 1) were initially interpreted as a metamorphic sole generated during ophiolite obduction (Avias, 1967). However, this model was subsequently discounted, and most authors (e.g. Briggs, 1975; Brothers, 1985; Yokoyama et al., 1986) considered the origin of the laterally extensive peridotite nappe $\left(>6000 \mathrm{~km}^{2}\right)$ in southwest New Caledonia as unrelated to the genesis of the high-pressure rocks of northeast New Caledonia. High-pressure metamorphism was linked to northeast directed thrusting (Lillie, 1975; Briggs et al., 1978). However some revision of these conclusions is necessary as a result of detailed work in northeast New Caledonia.

It is now evident that the original model of Avias (1967) cannot be set aside. Rawling and Lister (1999b) report the discovery of the high-pressure sole of the originally overthrust ophiolite. The eclogite-blueschist belt of northeast New Caledonia has been overthrust by a serpentinite sheet that contains a boulder mélange with relict high-pressure eclogite facies mineralogy. This overthrusting event may

\footnotetext{
* Corresponding author. Tel.: +61-3-9905-5774; fax: +61-3-9905-5062.
}

E-mail address: mhough@mail.earth.monash.edu.au (G.S. Lister). have been the cause of eclogite facies metamorphism in northeast New Caledonia.

Rocks in the eclogite facies slices in northeast New Caledonia (outcropping on the Pam Peninsula; Fig. 1) cooled below $\sim 300^{\circ} \mathrm{C}$ at about $40 \mathrm{Ma}$ (Rawling, 1998; Baldwin et al., in review). The main mass of the New Caledonia ophiolite was emplaced on thrusts that overrode sediments some time after $38 \mathrm{Ma}$ in central New Caledonia, and after $35 \mathrm{Ma}$ in southern New Caledonia (Cluzel, 1998; Cluzel et al., 1998). There is thus still support for the conclusion (see above) that the main mass of the New Caledonia ophiolite (in the southeast of the island) was overthrust in an event that was unrelated to the genesis of the high-pressure rocks in northeast New Caledonia (Briggs, 1975; Brothers, 1985; Yokoyama et al., 1986).

The concept (espoused by Lillie (1975) and Briggs et al. (1978)) that northeast-directed thrusting produced the eclogite-blueschist belt has significant limitations (Rawling et al., 1994; Cluzel et al., 1995; Rawling and Lister, 1999a). First it requires crustal thicknesses greatly in excess of those that can be accounted for in reconstructions of the thrust belt. Second, the geometry of southwest dipping foliations and arcuate faults southwest of the high-pressure zone is not consistent with a thrust geometry, particularly in view of the pattern of metamorphic grade increasing towards the 


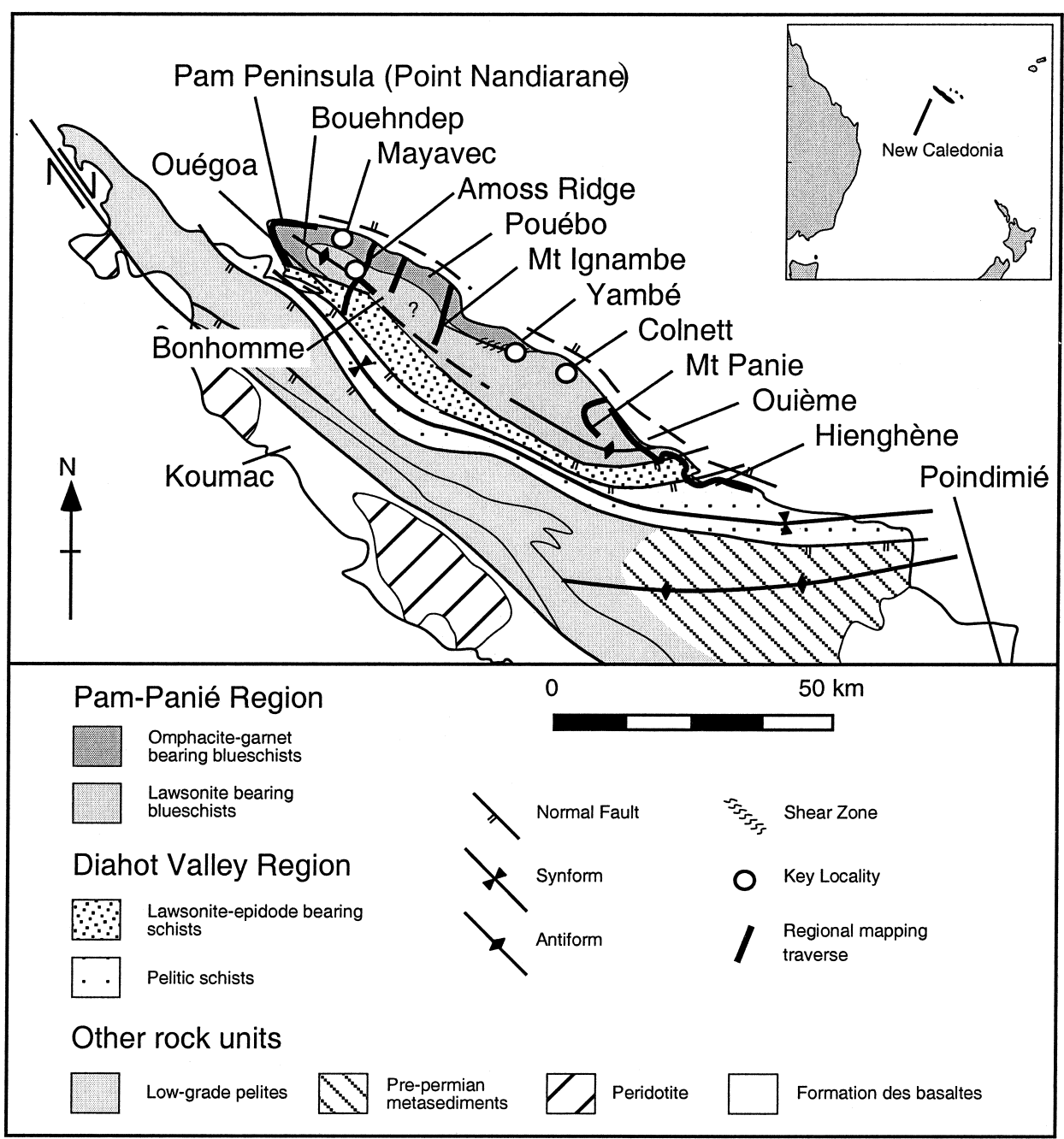

Fig. 1. Simplified geological map of northern New Caledonia showing extent of the Pam-Panié region and location of regional traverses and key localities.

northeast. This pattern is consistent with the effects of late stage extensional tectonism superimposed upon the geometry of an earlier formed collisional orogen (Rawling et al., 1994; Aitchison et al., 1995; Cluzel et al., 1995). Northeast-directed thrusting is "difficult to reconcile with southwest or south-southwest vergence of the contemporaneous ophiolitic nappe inferred from field or geophysical data" (quoted from Cluzel et al., 1995; see also Avias, 1967; Collot et al., 1987). Exhumation of the high-pressure rocks has also been considered as the result of wrench faulting (Black et al., 1993), but (as noted by Cluzel et al., 1995) kinematic data are not consistent with this interpretation.

Aitchison et al. (1995), Cluzel et al. (1995) and Clarke et al. (1997) interpreted the folded shear fabrics of the high pressure terrane as the domed mylonite front of a metamorphic core complex. Cluzel et al. (1995) and Clarke et al. (1997) stated that the highest grade metamorphic rocks are found within the core of this regional antiform (in the folded Pouébo terrane), and suggest a model that involved subduction of a continental mass, and then "crustal thinning and extensional detachment during the diapir-like uplift and unroofing of the eclogite core" (Cluzel et al., 1995). Clarke et al. (1997) suggested that gravitational sliding took place as the diapir-like core was emplaced, and as a result the coastal antiform shed lower-grade rocks to each side as it rose.

Concurrent research at Monash University initially supported the notion that core-complexes like those now found in the U.S. Cordillera once existed in New Caledonia. For example the existence of metamorphic core complexes in the Mayavetch region was proposed by Streets et al. (1994) and Streets (1995). However, there are no data that suggest that the extensional systems were ever exhumed to the point that the domes would have existed as geomorphological entities. It was thus incorrect for us to have argued that metamorphic core complexes had formed (although the data in support of the operation of extensional shear zones are still valid). Similarly, Aitchison et al. (1995) have been unable to support their (subsequent) assertion that the coastal antiform is a metamorphic core complex, in particular since the detachment fault proposed by these authors appears to be a younger (and unrelated) normal 


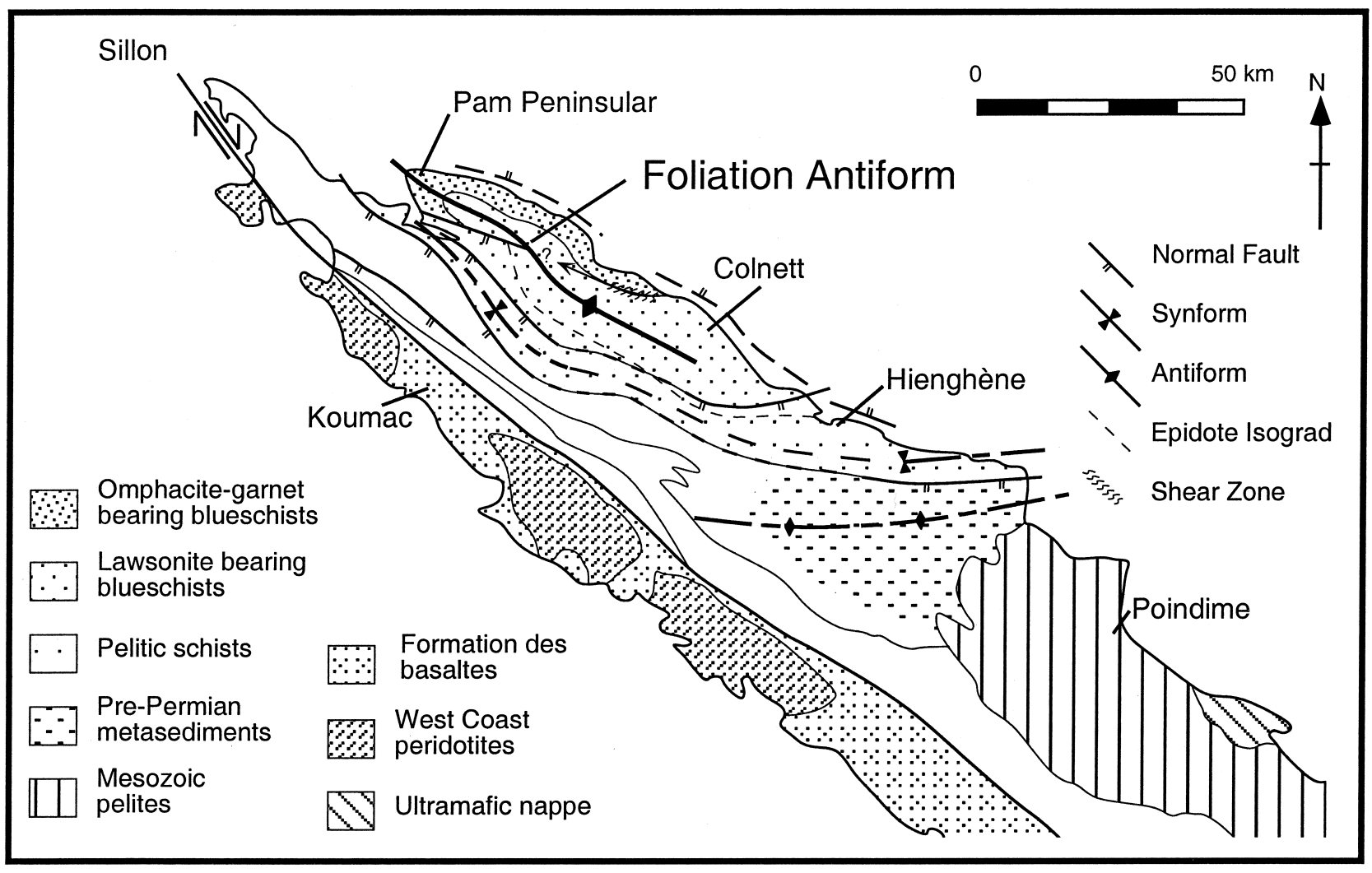

Fig. 2. Regional geology map of the Northern New Caledonia. The location of the 'foliation antiform' as described by Aitchison et al. (1995) is highlighted. Figure modified after Rawling and Lister (1999a,b).

fault (see below). The central issue in this debate is the origin of the coastal antiform (Fig. 2).

The 'foliation antiform' plays a significant role in the models developed by Aitchison et al. (1995), Cluzel et al. (1995) and Clarke et al. (1997). Therefore, we decided that further research in the Pam Peninsula was necessary to allow us to reanalyse the results obtained by these authors. We also wanted to understand why previous authors (e.g. Yokoyama et al., 1986) showed gently dipping isograd surfaces, whereas our research suggested this was an incorrect interpretation due to the misidentification of several low-angle normal faults as metamorphic isograds (Rawling and Lister, 1999a). It seems difficult to explain gently dipping isograds that have been extrapolated across younger normal faults without interruption.

Rawling and Lister (1999a) suggest a protracted history of orogenesis, involving multiple cycles of crustal shortening and later extensional tectonism. We support Aitchison et al. (1995), Cluzel et al. (1995) and Clarke et al. (1997) in respect of the concept of extensional tectonism leading to exhumation of the high-pressure rocks, but our results do not support the notion of a sequence of terranes with the highest pressure rocks at the core of a regional 'foliation antiform'. Our data suggests that the 'foliation antiform' is a relatively youthful feature that formed after the exhumation of the eclogite-blueschist belt had taken place. It had nothing to do with the formation of metamorphic core- complexes. The fault reported by Aitchison et al. (1995) as a detachment fault on the flank of a proposed core complex did not exist at the time the 'foliation antiform' developed.

A limited understanding of the large-scale geometry of the poorly exposed Pam-Panié region (Fig. 1) has always been a stumbling block to geometric and tectonic reconstructions of the evolution of the high-pressure schist belt of New Caledonia (Brothers and Blake, 1973; Bell and Brothers, 1985; Maurizot et al., 1989; Aitchison et al., 1995; Cluzel et al., 1995; Clarke et al., 1997). The only thorough analyses of the geometry of this region were published over 25 years ago by Lillie $(1970,1975)$. Therefore we decided to revisit this question and to conduct regional-scale structural mapping and sampling traverses in the Pam-Panié region, to constrain its large-scale structural geometry, and to ascertain why previous authors have arrived at what we now believe to have been erroneous conclusions.

Mapping was also carried out in the region of $\mathrm{Col}$ d'Amoss to investigate the nature of a number of lowangle structures described by numerous previous authors (Bell and Brothers, 1985; Yokoyama et al., 1986; Clarke et al., 1997). A larger-scale transect was made from Colnett to Hienghène. Structural transects were also carried out around Pointe Nandiarane on the Pam Peninsula, across the Amoss ridge, east from Col d'Amoss toward 


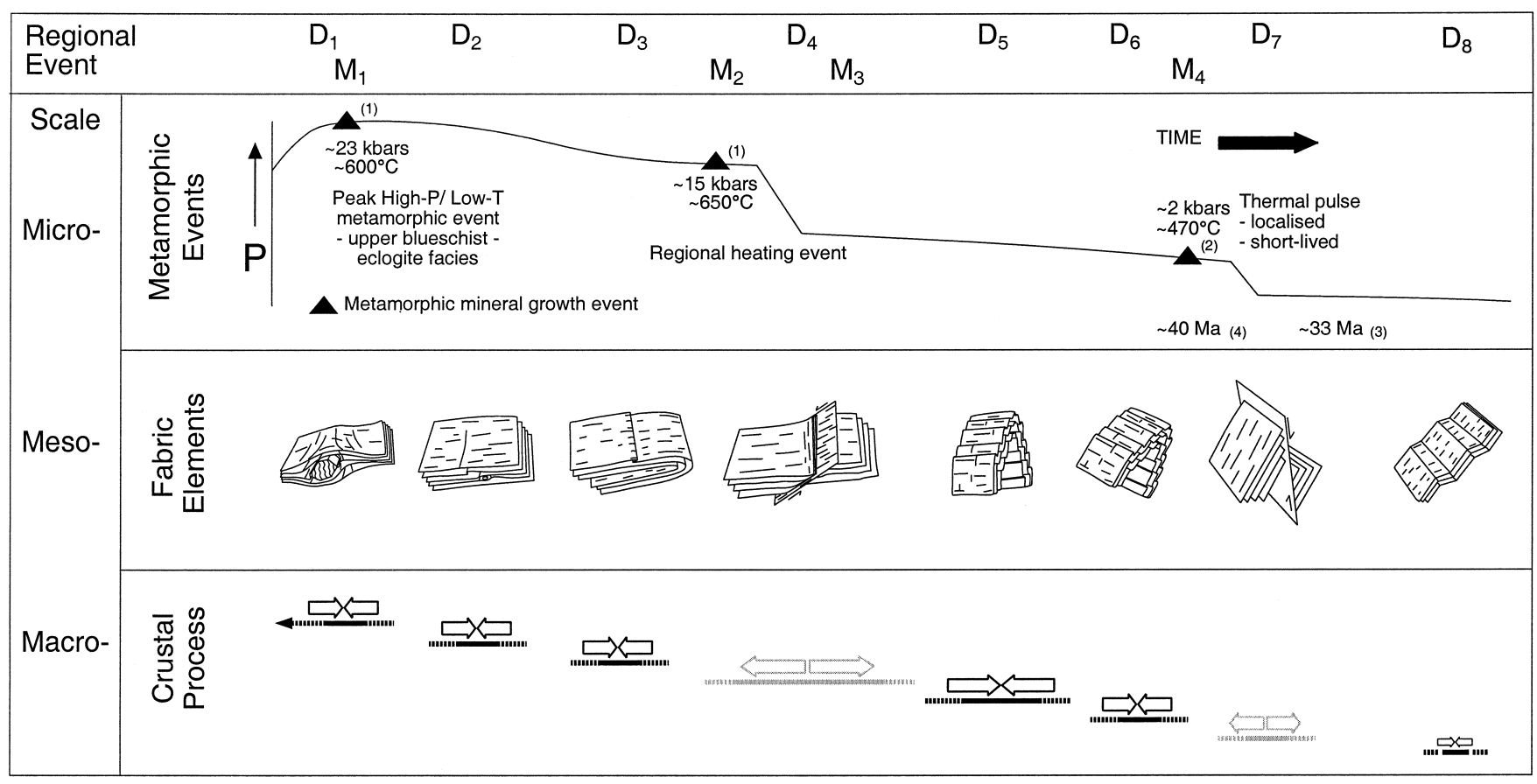

Fig. 3. Event diagram showing the effects of each deformation and metamorphic event on the rocks of the high-pressure schist belt at micro-, meso-, and macroscopic scales. See text for more detailed discussion.

Bonhomme, along the old road from Balade toward Ouégoa and from the coast to the peaks of both Mt Ignambe and Mt Panié (Fig. 1).

This research highlights the value of systematic structural analysis, beginning at mesoscopic scale, linking in the fabrics and microstructures, determining the nature, geometry and timing of the various identifiable mesoscopic fabric elements, and finally developing the ability to address orogen-scale issues (Rawling, 1998).

\section{The significance of early fabrics}

Lithological layering is common, and may be related to bedding in metasediments. In places pillow-basalts can be recognised, often with an eclogite or blueschist facies metamorphic overprint. Early-formed schistosity is likely to be related to overthrusting, but the geometry of early fabrics cannot be readily extrapolated from location to location because of the complexity of overprinting structure and poor outcrop. It is therefore difficult to map out the shape of early thrust sheets, except where lithological contrast makes this immediately evident (e.g. where eclogites in mafic rocks and metasediments contrast with juxtaposed serpentinites). Detailed structural analysis at the scale of the outcrop (confirmed by later fabric and microstructural examination of selected hand-samples) invariably reveals the presence of a complex history of deformation and metamorphism. But the presence of an early $\left(S_{1}\right)$ schistosity is usually confirmed (Fig. 3).

The first penetrative fabric that can be mapped through the eclogite-blueschist belt is defined by differentiated crenulation cleavages, formed during $D_{2}$ (Fig. 4a). Again the complexity of later (overprinting) deformation makes the geometry of $S_{2}$ difficult to determine on the largescale. The regional attitude (and overall enveloping surface) of $S_{2}$ fabrics tends to be steep, although locally $S_{2}$ has been thrown into cascades of recumbent folds by the $D_{3}$ deformation (Fig. 4b). $D_{4}$ shear zones (referred to here as middlestage shear zones) throw all previously formed fabrics into gently inclined orientations (Fig. 4d). The $D_{4}$ shear zones define the oldest large-scale structures that can be mapped with confidence across the region.

\section{Middle-stage ductile shear zones}

At a number of locations on the flanks of the coastal range on the Pam Peninsula, major ductile shear zones can be identified. Based on key locality mapping and detailed analysis of the fabrics and microstructures, these appear to have formed in the middle stages of a complex metamorphic history $\left(D_{4}\right)$ after high pressure metamorphism, but prior to a late-stage upper greenschist-facies thermal overprint (Fig. 3).

These middle-stage shear zones dip moderately down the flanks of the coastal range to the southwest (in the $\mathrm{Col}$ d'Amoss region) and also to the north and to the northeast (in the Mayavetch and Amoss streams). The largest of the shear zones is the most striking feature of the Amoss Ridge region when viewed from the Col d'Amoss (Fig. 5a). These zones are commonly offset or overprinted by later brittle faults (see below). 



d)
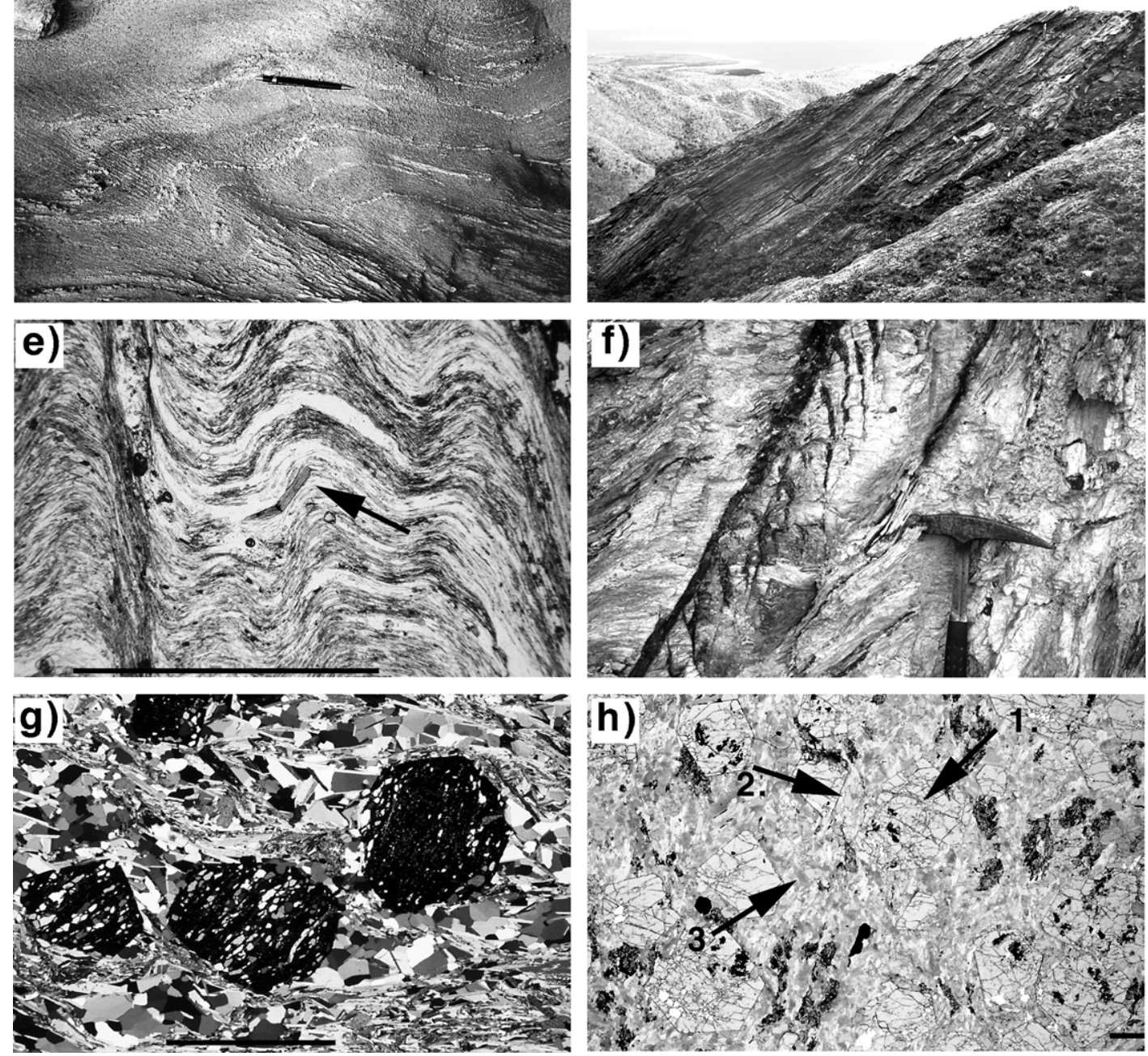

Fig. 4. (a) Foam textured grains of quartz and phengite define the dominant differentiated $S_{2}$ fabric. Sample is from the Mayavetch Stream and scale bar is $2 \mathrm{~mm}$. (b) Detail of $D_{4}$ shear zone. Note the strung-out rootless isoclines of quartz adjacent to which a folded relict differentiated $S_{2}$ fabric can be identified. Shear sense is dextral. (c) Ductile shear fabric from within a middle stage shear zone that has been folded and overprinted by a later crenulation fabric. (d) Large-scale northeast dipping ductile $D_{4}$ shear zone at the Amoss Ridge. This is a distal view of a similar shear zone to that pictured in (b) of this figure. Note the large (metre-scale) foliation boudinage structure with a quartz filled boudin neck in the central part of the shear zone (base of photograph is $20 \mathrm{~m}$ ). (e) Upright crenulation cleavage that folds $L_{2}$ glaucophane lineations and the differentiated $S_{2}$ fabric. Sample is from the Point Nandiarane region and scale bar is $5 \mathrm{~mm}$. (f) Tension gashes in the footwall of a quartz-filled normal fault adjacent to the Gendarmerie Fault in the Diahot Valley. Note the development of quartz-filled fractures that are parallel to the fault surface (above the hammer in this photograph). (g) Photomicrograph showing preservation of the $S_{2}$ fabric within garnet porphyroblasts from the Mayavetch Stream, indicating syn- $D_{2}$ garnet growth in this region. Photomicrograph is in crossed polarised light and scale bar is $2 \mathrm{~mm}$. (h) Photomicrograph of an undeformed eclogite sample from within the boulder mélange unit in the Amoss Ridge region. Photomicrograph is in plane polarised light and contains (1) garnet, (2) omphacite, and (3) glaucophane. Scale bar is $1 \mathrm{~mm}$. 

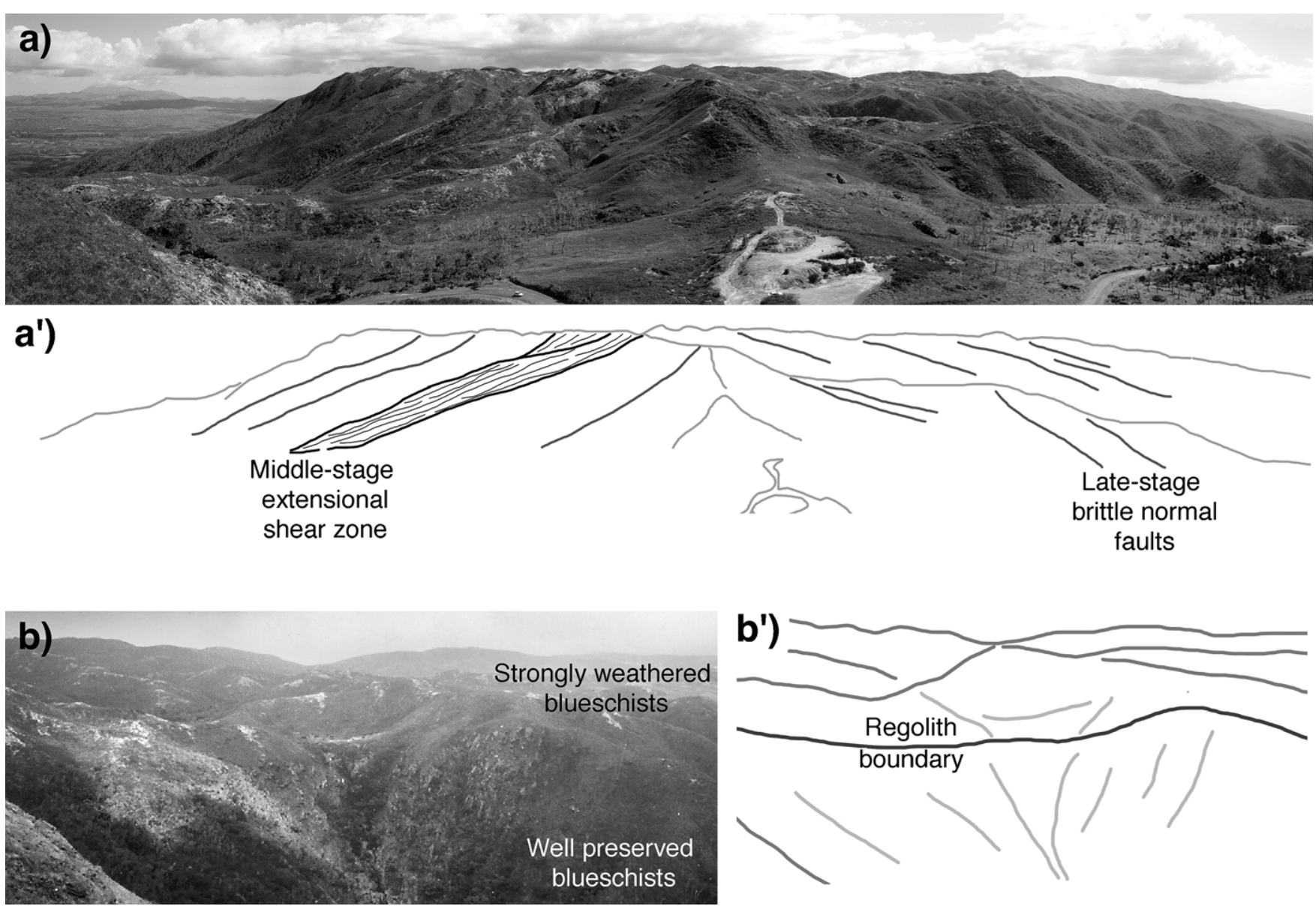

Fig. 5. (a) and $\left(\mathrm{a}^{\prime}\right)$ Photograph and accompanying sketch of the Amoss ridge facing NW. These images show the location of several late normal faults and disrupted middle-stage extensional shear zones. A car can be distinguished in the car-park in the middle of the photograph for scale. (b) and ( $\left.b^{\prime}\right)$ Photograph and accompanying sketch of the flat weathering surface at the head-waters of the Amoss Stream. Photograph is taken facing north from the Amoss ridge and spans approximately $400 \mathrm{~m}$.

The timing of these shear zones can be demonstrated to be synchronous with regional $D_{4}$ based on overprinting relations (e.g. in the Amoss Ridge and Mayavetch Stream: Streets, 1995; Rawling, 1998). The largest of the shear zones exposed on the Amoss Ridge is in excess of $15 \mathrm{~m}$ thick (this estimate is constrained by outcrop dimensionthe base of the shear zone has not been mapped). Abundant kinematic indicators suggest a consistent normal sense-ofmovement, i.e. upper block to the south or southwest. Similar smaller-scale ductile shear zones are identified in the Mayavetch Stream (Figs. 1 and 6) dipping to the north or northeast again with a normal sense-of-movement (i.e. upper block to the north or northeast).

These shear zones are commonly (tightly) folded by upright but steeply plunging $D_{5}$ and $D_{6}$ folds. The orientation of these shear zones have thus been substantially modified and steepened during subsequent upright folding (Fig. 4b). If the effect of this (later) folding is removed the opposite dipping shear zones at the Mayavetch Stream and at the Amoss Ridge appear to represent low-angle shear zones of the same age but with different orientation and movement sense (Fig. 4a). Movement on the opposite facing shears would have resulted in significant unroofing of the high pressure schist belt. $D_{4}$ is thus a period of extensional tectonism.

It is difficult to time the formation of shear fabrics in all cases. Locally the ductile shear fabrics that define these shear zones appear to be the youngest fabrics, but this is the case only adjacent to regions where $S_{5}$ and $S_{6}$ axial planar crenulation cleavages are strongly developed and overprint all older fabrics. The intensity of later strain makes it difficult to recognise older deformation fabrics. Close examination of some of the larger shear zones in this category shows young crenulations that are well developed in adjacent schists and also present in the shear zone. In the shear zone, these young crenulations have been strongly overprinted by (ongoing?) shear zone deformation, and thus partially obliterated. This observation indicates that some (but not all) of the larger-scale $D_{4}$ shear zones were reactivated during later stages of the deformation history. This period of reactivation is interpreted to have occurred synchronously or immediately prior to the formation of brittle normal faults associated with extensional tectonism, and is described later in the paper (see Section 5). 


\section{The structure of the gneissic core and the 'foliation antiform'}

The structure of the Pam Peninsula has previously been described by a number of authors as antiformal (Maurizot et al., 1989; Aitchison et al., 1995; Cluzel et al., 1995; Clarke et al., 1997). Detailed mapping across the Pam Peninsula and around its northwest tip shows this to be generally true. However, a couple of important elements of the geometry must be considered. (1) What is being folded? (2) How do the complexly folded schists in the core of the antiform relate to the overall structure?

\subsection{Large-scale structure and vergence}

Three detailed structural mapping traverses were undertaken in the Pam-Panié region in order to investigate the nature of the large-scale structural geometry of the coastal range (Fig. 2). In particular the mapping was designed to test whether or not the high-pressure rocks are exposed within the core of a large-scale foliation antiform, as proposed by a number of previous workers (Lillie, 1975; Maurizot et al., 1989; Aitchison et al., 1995; Cluzel et al., 1995; Clarke et al., 1997).

The first traverse cut across the northwestern tip of the Pam Peninsula at Pointe Nendiarane (Fig. 1). Based on the mapping of Lillie (1970, 1975), this is the region where the northern nose of the antiformal structure should be encountered. The second traverse (Fig. 1) crosses the Pam-Panié region by following Route 1 from the coast, through Col d'Amoss to Ouégoa. This also incorporates data collected along the abandoned road that crosses the coastal range at Col d'Parari northwest of Pouébo. A third traverse was undertaken along the coastal road between Colnett and Hienghène (Fig. 1). This is the region in which Lillie (1975) interpreted several large-scale structures, based on the identification of Tertiary metasedimentary protoliths near Ouième (Fig. 1).

Mapping of coastal outcrops and road sections in the Pointe Nendiarane region (Figs. 1 and 6) reveals clear evidence for a large-scale antiformal closure. The 'nose' of the structure can be identified on the roadcutting $\sim 100$ m east of Pointe Nendiarane (Fig. 8). A major change in large-scale vergence coincides with this structure (Figs. 6 and 7 ) based on the analysis of numerous vergence indicators including the asymmetry of mesoscopic folding. It is clearly evident that this structure has an upright axial planar crenulation cleavage $\left(S_{5}\right)$ that microfolds all older fabrics in the region (Fig. 4e). Analysis of these structures also reveals a consistent change in vergence about the inferred axial trace of the antiformal structure. Asymmetric parasitic folds consistently plunge to the north-northeast at $\sim 13^{\circ}$. Based on statistical analysis of cleavage relations, the large-scale antiform is upright and plunges gently to northwest $(18 \rightarrow 348)$, with an axial plane dipping $83^{\circ}$ towards $078^{\circ}$.
The coastal antiform is best defined in this region by the reorientation of the well developed differentiated crenulation cleavage although it is also evident in folded relict primary layering in quartz-mica schists. Locally centimetre-scale discrete shear zones crosscut and deflect this fabric and these too are folded. The well developed upright crenulation fabric $\left(S_{5}\right)$ overprints both the differentiated crenulation cleavage and the shear bands and is axial planar to folds parasitic on the larger scale antiformal closure. Zones of high silicification and tension gashes are common and approximately parallel with the axial plane in this region (Fig. 4f).

The rocks in this region are typically strongly weathered and altered. Nevertheless, relatively detailed studies of the petrology of this region have been published by Yokoyama et al. (1986), Bell and Brothers (1985), Black et al. (1988) and more recently by Clarke et al. (1997). The rocks are typically glaucophane-rich and garnetiferous. The timing of garnet growth is apparently synchronous with development of the dominant differentiated crenulation cleavage (Fig. $4 \mathrm{~g}$ ). Based on the overprinting relationships observed in the Diahot Valley region and the Pam-Panié region (Rawling, 1998; Rawling and Lister, 1999a), the differentiated crenulation cleavage is interpreted to be regional $S_{2}$ and the upright folds are $D_{5}$ or $D_{6}$ structures.

Although mapping between Ouégoa and the northeast coast is less conclusive, evidence still exists for a large scale antiformal culmination in this region. Throughout this traverse, upright mesoscopic folding of more than one generation is common $\left(D_{5}\right.$ and $\left.D_{6}\right)$. The vergence defined by the asymmetry of the mesoscopic $F_{5}$ folds is consistent between Ouégoa and Col d'Amoss indicating an antiformal closure to the northeast. However, between Col d'Amoss and the coast, well exposed basement gneiss is rare and structural trends cannot be traced out over any distance. Where the basement is exposed, care must be taken as a number of these outcrops are strongly affected by downslope creep.

Two well exposed and relatively fresh outcrops have been identified. The first of these is halfway from Col d'Amoss to the coast on a right hand bend in the road at $230 \mathrm{~m}$ elevation. The second is in a small creek at the base of the descent. Whilst the interpretation of vergence relationships in the roadcutting is somewhat ambiguous, the relationship at the base of the hill clearly indicates a change in largescale vergence between this locality and Col d'Amoss. It is possible that the axial zone of the antiform is located in the region of the roadcutting resulting in the variable vergence relationships at that locality (Figs. 1, 6 and 7).

Mapping along coast in the region between Colnett and Hienghène also reveals evidence for a large-scale vergence change (Fig. 6). However, overprinting by several generations of structures and subsequent dismemberment by lowangle normal faults that dip towards the sea (northeast) complicates the identification of the axial zone to the large-scale fold. Mapping in this region is also complicated 




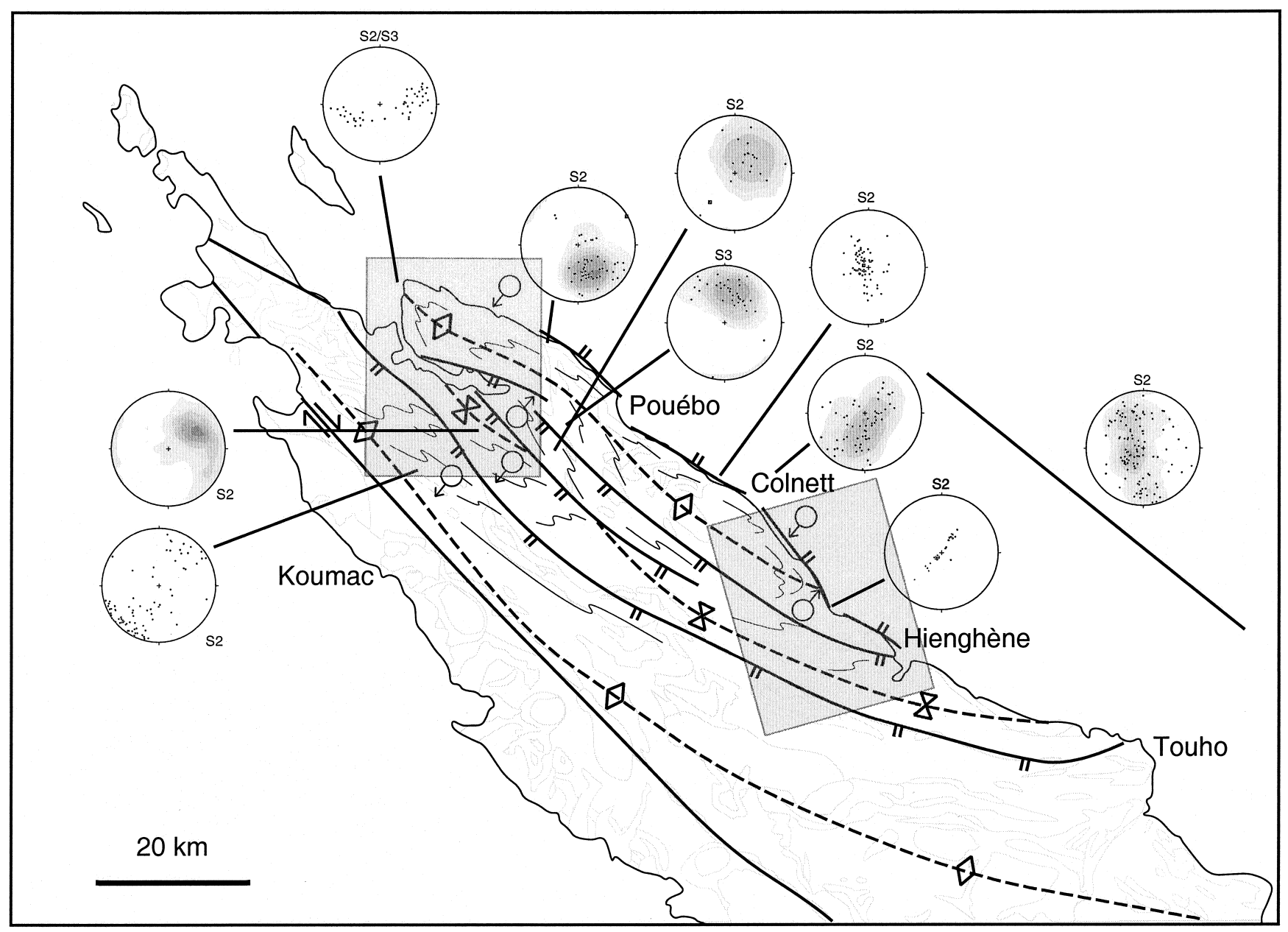

Fig. 7. Generalised structural element map of the Pam-Panié region and adjacent Diahot Valley region showing large-scale form surfaces, stereonets describing the dominant $S_{2}$ fabric orientations and vergence indicators across the belt. Greyed boxes indicate position of maps presented in Figs. 6 and 8 .

by the oblique intersection of $D_{5}$ structures with many road cuttings and coastal outcrops. Nevertheless, the evidence for a large-scale change in vergence in this region is convincing. Mesoscopic folding is common and asymmetry of these folds changes several times between Colnett and Hienghène. This makes the identification of a single axial zone somewhat more difficult and may indicate that the form of the fold is broader in this region and may include a number of large-scale sub-folds (Figs. 6 and 7). The interpretation of regional structural data from the ColnettHienghène region (Figs. 7 and 8) indicates that the foliation antiform also plunges gently to the southeast in this region.

\subsection{Geometry}

Analysis of the antiformal structure in the Pam-Panié region shows the fold is laterally continuous for over $60 \mathrm{~km}$. The amplitude and wavelength of the fold are difficult to ascertain due to the dismemberment of the structure by late faulting. However, the identification of consistent vergence relationships over a $20 \mathrm{~km}$ traverse (crossing only one major axial zone) in the Amoss region suggests wavelengths on the order of $\sim 40 \mathrm{~km}$. This is an orogen-scale structure.

Mapping in the Pointe Nendiarane and Ouième regions indicate that the antiform is weakly doubly plunging and that that axial plane has an arcuate trace. The fold plunges between 10 and $20^{\circ}$ to the north-northeast at Pointe Nendiarane and plunges at similar angles to the east at Ouième.

We believe that the structure represents a large doubly plunging antiform with a geometry that was not influenced

Fig. 6. Geological map of the Pam Peninsula and Diahot Valley regions. Two cross-sections through the highest grade metamorphic rocks in the Pam Peninsula are included. The first, A-B, crosses Col d'Amoss between the town of Ouégoa and the coast. This section highlights the original extent of the overthrust ophiolite sheet and its relationship to the ophiolitic remnants and boulder melange described in this paper. The second, C-D, shows the antiformal nature of the northern tip of the Pam Peninsula. See Fig. 7 for map location. 






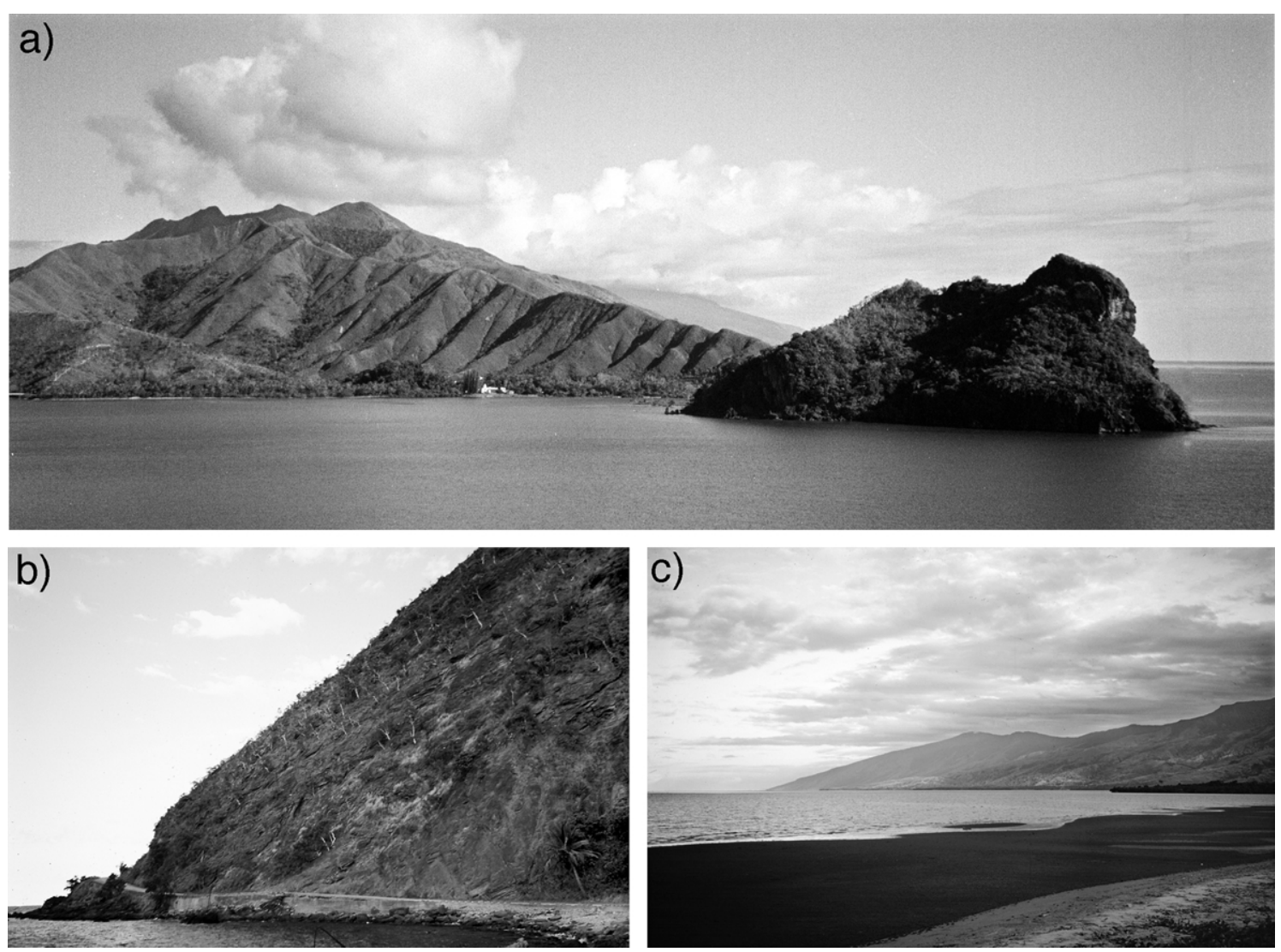

Fig. 9. Photographs of late seaward dipping normal fault scarps along the northeast coast of the Pam Peninsula. (a) View of NE dipping normal fault scarp looking northwest from the Hienghène township. Note the island composed of recrystallised but weakly metamorphosed karst limestone in the hanging wall separated from the glaucophane-bearing schists of the high-pressure metamorphic belt in the footwall. Mt Panié is the highest peak in the background. (b) View SE from the river at Ouième of a steeply dipping $\left(45^{\circ}\right)$ normal fault scarp that defines the coast in this region. (c) View SE from Pouébo showing shallow NE dipping fault that controls the geomorphology in the Colnett region at the foot of Mt Panié.

by earlier tectonism (i.e. the domal morphology was not produced during earlier extensional tectonism). Low-angle zones or detachments folded during intense non-coaxial deformation formed doubly plunging folds at all scales, resulting in the elongate doubly plunging fold geometry of the belt today. Similar $F_{5}$ non-cylindrical folds can be identified at mesoscopic scale with the same geometry as the orogen-scale structures.

\section{Late stage normal faulting, shear zone reactivation and block faulting}

Localised ductile reactivation of moderately dipping $D_{4}$ shear zones occurred subsequently to the $D_{5}$ and $D_{6}$ folding events in the Amoss region. Ductile reactivation of these shear zones is spatially and temporally related to the widespread development of steeply to moderately southwest dipping brittle normal faulting. As a result a second period of extensional tectonism is interpreted to have been initiated, subsequent to regional upright folding, that initially resulted in localised ductile shearing but evolved into a period of brittle normal faulting.

One of the most striking features of the large-scale morphology of the Pam-Panié region is the linear trend of the coastal range and the arcuate nature of the boundary with the lower grade rocks to the southwest. The geomorphology of the northeast coast is dominated by extensive planar land surfaces that dip at low-angle to the sea (northeast). These surfaces are interpreted to represent normal fault scarps that have retreated to variable extents owing to the high rates of erosion in this region (Fig. 9). They define a classic normal fault scarp geomorphology along the coast (similar to that seen in Crete; Stewart and Hancock, 1991). The present geomorphology of the PamPanié region thus appears to be controlled by block-faulting,

Fig. 8. Simplified form surface map from the Colnett-Hienghène traverse showing the location of the antiformal closure and Hienghène normal fault. Stereonets are included that show the orientation of the dominant $S_{2}$ fabric, $F_{5}$ folds and $L_{2}$ extension lineations. The greyed region contains lawsonite and glaucophane-bearing schists and the stippled region is dominated by weakly metamorphosed pelites. See Fig. 7 for map location. 
and the subsequent erosional exhumation of an architecture defined by middle- and late-stage ductile shear zones and faults.

The fault scarps on the northeast margin of the coastal range are the least strongly eroded, and they juxtapose rocks with different metamorphic histories (for example in the Hienghène region). The upper plates of these systems are typically submerged offshore, however. The downthrown (hanging wall) block is rarely preserved along the northeast coast except at Hienghène where a series of outcrops of recrystallised limestone are exposed along the coast and offshore as small islands. These limestones have a karst morphology and are substantially lower grade than the adjacent glaucophane and lawsonite-bearing micaschists. The limestone unit is interpreted to have resided much higher in the sequence at the time of metamorphism and to have been tectonically juxtaposed against the high-grade metamorphic rocks as a result of movement along brittle northeast dipping normal faults. Similarly oriented northeast dipping normal faults have also been identified offshore in the South Loyalty Basin (Lafoy et al., 1996).

Scarps similar to those along the northeast coast have also been identified to the southwest of the axis of the range between Col d'Amoss and Ouégoa. However, the fault surfaces are less well preserved and slopes are incised by more mature drainage systems. Quartz-filled fault breccias and gouge deposits are common in the Amoss Ridge region and are associated with normal faults of this generation. The faults in this region also strike to the northwest but are generally steeper dipping at between 30 and $80^{\circ}$ to the southwest. These faults are commonly associated with the reorientation of pre-existing structures and are interpreted to be of the same generation as the brittle normal faults that dissect and reorient blocks within the Diahot Valley region (Rawling and Lister, 1999a).

A steeply south dipping and east-west striking fault has also been identified in the Hienghène region based on similar structural relationships. This fault is interpreted to be a southern equivalent to the steeply dipping Gendarmerie Fault near Ouégoa. This system of steep normal faults effectively isolates the Pam-Panié region from the lower grade rocks of the Diahot Valley region (Fig. 6).

The timing of movement on the brittle normal faults described above is likely to have occurred at, or prior to, $32 \mathrm{Ma}$ as fission track data from the coastal range indicates that exhumation of the high-pressure belt was largely completed by this time (Baldwin and Verts, 1997; Baldwin et al., in review).

Evidence for large-scale block faulting was revealed as a result of detailed structural analysis of the region between the tip of the Pam Peninsula and the Bondé-Ouégoa. This style of faulting is considered to be distinct from the brittle normal faulting and shear zone reactivation described above due to the geometry and orientation of the faults as well as the substantially smaller throw on the faults of this type.
However, the timing of this faulting may well be coincident with the brittle normal faulting event.

These late structures considerably complicate the geometry and orientation of earlier formed folds and shear zones and locally juxtapose elements from different structural levels (for example schists or gneisses of the metamorphic core with glaucophanite boulders and serpentinite of the serpentinite sheet). Late movement on these steeply dipping fault surfaces has resulted in vertical offset of the recent weathering surface and thus facilitated different levels of weathering within different fault-bound blocks.

In the field there are numerous quartz-filled minor faults, quartz veins and other evidence for very late faulting. However, little evidence exists to suggest that there has been rotation or reorientation of structures of fault-bound blocks associated with this period of brittle faulting. Most of the movement would appear to have been vertical and in the order of 1-10 m displacement. A number of small, 1-4 m high, degraded scarps can be identified in the Col d'Amoss region. Whilst the fault surfaces themselves are typically obscured in the field there appear to be two sets of high angle faults oriented at about $60^{\circ}$ to each other. Activation of these faults may have occurred during neo-tectonic or older surface uplift associated with the development of the high-relief of the Panié Massif.

\section{Structures(?) formed by tropical weathering}

Many previous workers have mapped low-angle faults, shallowly dipping isograds or stratigraphic contacts within the Amoss ridge region (e.g. Bell and Brothers, 1985; Yokoyama et al., 1986).

However, we found little or no evidence for such structures. The most obvious planar feature within the Pam Peninsula/Col d'Amoss region is a flat-lying surface that appears to separate deformed and friable lower grade rocks from more 'massive' higher-grade schists and gneisses. This low-angle surface is traceable for tens of kilometres both in air photographs and the surface geology (Fig. 5). Close examination of the schists from above and below the flat-lying surface reveals them to be very similar both in terms of their structure as well as their composition. The only apparent difference between the rocks exposed above and below this surface is the severity of weathering. Examination of the surface itself suggests that it, in fact, represents the base of a tropical weathering profile.

Throughout much of this region at least three fabrics are locally very strongly developed (two crenulations and one differentiated fabric). All of these fabrics dip steeply to vertically. Thus, infiltration of meteoric fluid is facilitated and weathering and dissolution rates intensified.

Obviously the high (tropical to sub-tropical) rainfall in the region plays a role in the weathering rates. Indeed many of the creeks throughout the Pam Peninsula are fed by springs high in the range that commonly appear to be 
a)

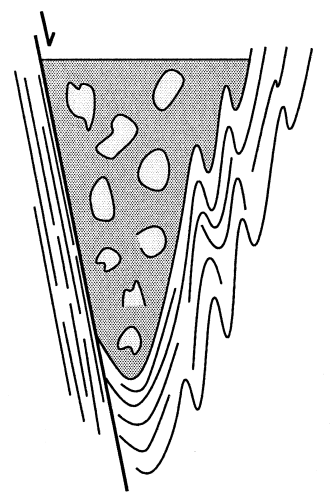

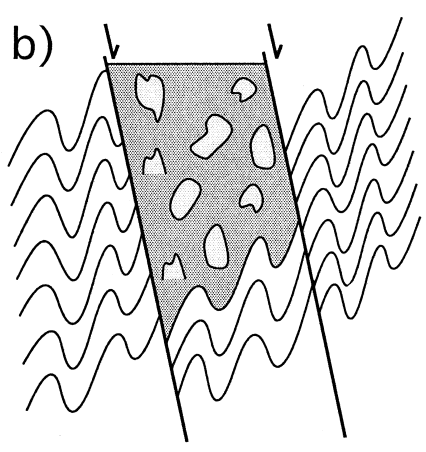

Fig. 10. Illustrations of (a) infold of knocker bearing serpentinite (grey) with sheared or faulted out limb; (b) downthrown block-fault bound section of knocker bearing serpentinite (see text for more detailed explanation).

sourced from along the weathering surface. These springs flow even during sustained periods of low rainfall indicating that large volumes of meteoric water are trapped in the more strongly weathered rocks above the surface.

The tropical weathering surface is locally displaced and offset during a very late stage period of block faulting that resulted in the final stages of surface and rock uplift in the region (see below).

\section{Discovery of a mantling serpentinite sheet}

The presence of significant volumes of serpentinite material in the Pam-Panié region has long been recognised (Lillie, 1970; Brothers and Blake, 1973; Lillie, 1975; Black and Brothers, 1977). Our structural mapping in the region of the serpentinite bodies revealed that serpentinite always occupies the structurally highest position (Figs. 6 and 10). The various serpentinite bodies appear to be remnants of a continuous serpentinite sheet (Fig. 11) that once overlay all or much of the high-pressure metamorphic belt above a lowangle detachment surface, presumably (originally) a major thrust. The effects of middle-stage upright folding mean that the dominant fabric within the serpentinite sheet is often contorted (Fig. 11) but it can always be restored to a flatlying or gently dipping orientation. This fabric is interpreted to have formed during the emplacement of the serpentinite mélange.

What remains of the serpentinite sheet is today exposed as a series of 'abandoned' sheets of serpentinite containing a boulder mélange with blocks of various compositions and levels of structural complexity. Remnants of the serpentinite sheet are also exposed as tight upright infolds (some of which may have faulted out limbs; Fig. 10) or occasionally



Fig. 11. (a) Schematic representation of opposite dipping, normal sense, ductile shear zones separating the siliceous high-pressure metamorphic core (medium grey) from well preserved high-pressure ophiolites (dark grey) and lower pressure meta-sediments (light grey). (b) The same shear zone system subsequent to large-scale upright folding. (c) Reactivation of segments of the ductile shear zone during late-stage normal faulting (note: the vertical exaggeration in this figure is significant). 

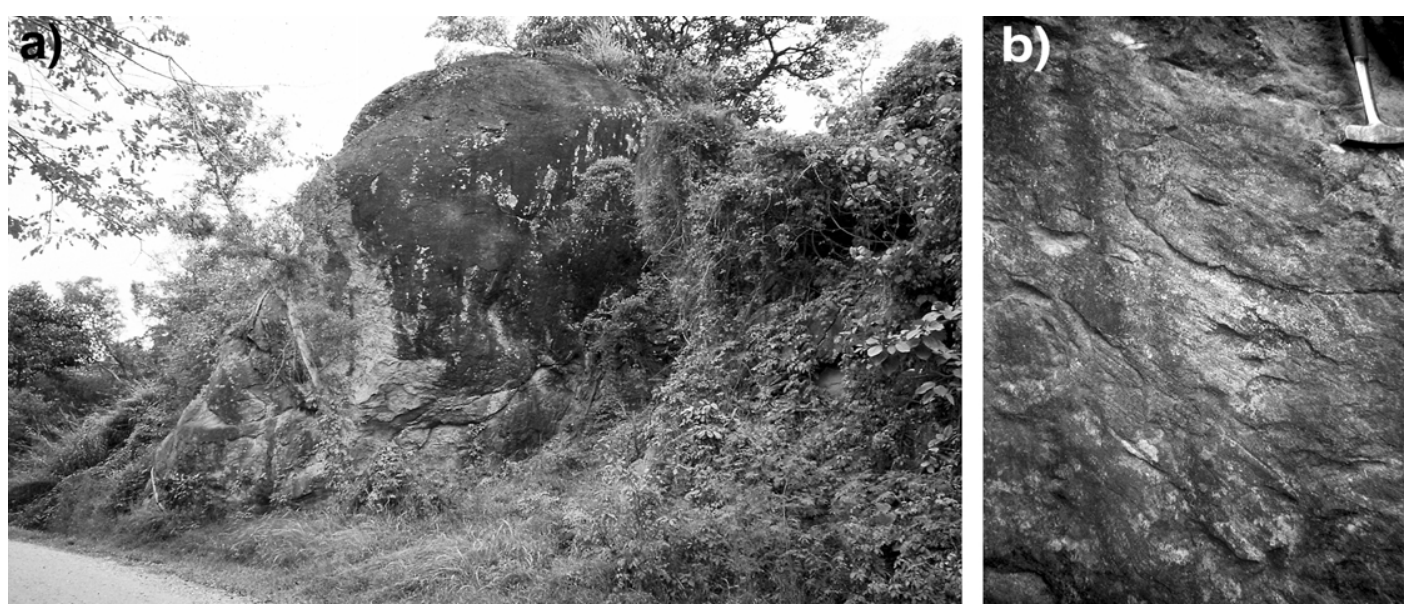

Fig. 12. Photographs showing the field expression of mafic eclogite blocks within the boulder melange. (a) Large (3.5 m high) boulder mélange block in the Ouième region. (b) Grooves angled from top-left to bottom-right of the photograph on the surface of the same block. The grooves formed as a result of interaction with other material within the boulder melange during overthrusting of the original ophiolite sheet in the Pam Peninsula region.

as discrete blocks completely bound by steep brittle block faults (Fig. 10).

The internal structure of the serpentinite sheet is very strongly foliated often sub-parallel to the underlying detachment surface. However, due to the propensity for serpentinite and talc assemblages to deform, numerous younger fabrics strongly overprint the detachment-parallel fabric locally. Fabrics commonly wrap blocks within the boulder mélange and are well developed in alteration skins around these bodies. Fabrics within the blocks themselves are variably developed. The fabrics within the blocks are not necessarily attributed to the same event as the fabric within the surrounding serpentinite as the competent blocks are effectively shielded from strain by the very weak matrix material that surrounds them. Those blocks that do contain well developed fabrics are often very similar in terms of their lithology and the structures preserved within them to coherent rocks of the lower plate. These blocks may represent 'plucked' boulders that were sourced from within the lower plate and tectonically removed and entrained in the serpentinite sheet.

The overthrusting of this ophiolitic sheet is interpreted to have resulted in significant crustal thickening and been critical to high-pressure metamorphism in the region. The identification of undeformed and fresh (non-retrogressed) eclogitic assemblages in blocks within the sheet, as well as more strongly deformed and locally retrogressed coherent eclogites in the lower plate, indicates that both the serpentinite sheet and the gneissic core were subjected to high-pressure metamorphism.

\section{Entrained high-pressure boulder-mélange within the serpentinite sheet}

The blocks that comprise the boulder-mélange are entrained within the serpentinite sheet and vary con- siderably in size, composition, internal structure and metamorphic grade.

The size of the blocks range from $\sim 2 \mathrm{~m}$ diameter to in excess of $50 \mathrm{~m}$ diameter. These are typically exposed as stranded boulders where the easily eroded enclosing serpentinite sheet has been removed. At some localities the serpentinite material has been entirely removed resulting in the 'deposition' of discrete eclogitic blocks onto the underlying gneissic core.

The blocks exhibit a rounded boulder-like morphology (Fig. 12). At some rare localities recent erosion of the much softer enclosing serpentinite reveals that the blocks have a smooth external surface that locally contains $1-5 \mathrm{~cm}$ wide and 10-60 cm long grooves or gouges (Fig. 12). These structures are interpreted to have formed as a result of frictional interaction between the blocks during the tectonic emplacement of the serpentinite sheet and to be analogous to grooves produced in glacially transported pebbles and boulders.

The composition of the blocks is variable throughout the Pam-Panié region. Lithologies include undeformed garnetrich eclogites (garnet + omphacite + glaucophane + epidote + quartz \pm rutile \pm clinozoisite \pm chlorite \pm pyrite) (Fig. 4h), undeformed glaucophanites (glaucophane + garnet + phengite + epidote + quartz \pm clinozoisite \pm chlorite \pm pyrite) and strongly deformed retrogressed eclogite (glaucophane + garnet + relict omphacite replaced by clinozoisite and chlorite + phengite + epidote). Alteration zones composed of talc, actinolite-tremolite and anthophylite-gedrite encase mafic blocks as skins.

The retrogressed eclogite blocks are very strongly deformed by the regional $S_{2}$ differentiated crenulation cleavage and locally contain $F_{2}$ or $F_{3}$ isoclinal folds but are not folded by the more open $F_{4}$ folds common at in situ outcrops of the basement gneiss. These rocks are very similar to those exposed as basement within the Mayavetch Stream and are interpreted to have been 
plucked from the gneissic lower plate during this period of thrusting.

The weakly deformed to undeformed eclogite and blueschist blocks are interpreted to be oceanic crust (dominantly metabasite but potentially also including peridotite fragments in the regions of high serpentinisation) that was thrust over the sediments and igneous rock now exposed in the core of the belt during crustal thickening.

The identification of the eclogite-bearing units as sheetlike and intimately associated with serpentinite is critical to realising that these units currently occupy a structurally higher position than the more retrogressed and altered gneisses and schists of the metamorphic core. It is important to note that whilst the latter rocks are strongly deformed and retrogressed (relative to the ultramafic blocks), omphacite and garnet as well as a number of other high-pressure minerals have been identified in these sequences (Yokoyama et al., 1986; Clarke et al., 1997) indicating that these rocks have also experienced very high pressure conditions.

\subsection{The basal contact to the serpentinite sheet}

Removal of the overprint of late normal and block faulting simplifies the nature of the contact between the serpentinite sheet and the underlying schists and gneisses. The contact itself is rarely exposed but appears to be a relatively low-angle fault or detachment surface. Strong shear fabrics form in both upper and lower plates adjacent to the fault and smaller discrete shear zones (centimetre to metre scale) descend into the lower plate and are commonly metasomatically altered.

Slivers of serpentinite material in the Mayavetch region are interpreted to have been emplaced as a result of thrusting during regional $D_{2}$. These rocks are always exposed in the upper plate of small thrust systems that represent microcosms of the larger-scale serpentinite sheet emplacement. Thus the basal contact is interpreted to be a low-angle thrust along which the ophiolitic material was tectonically emplaced at the time of crustal thickening and high-pressure metamorphism (regional $D_{1}-D_{2}$ ).

It is highly likely, however, that this structure was reactivated during the earliest stages of extensional tectonism and exhumation, as the serpentinite-filled fault zone would have been the major pre-existing crustal weakness at this time. The $D_{4}$ shear zones described above may in fact represent splays off this major structure into the lower plate of the extensional system. Again the smaller-scale slivers of ophiolitic material exposed in the Mayavetch region show this relationship clearly. The serpentinite slivers were tectonically emplaced due to thrusting. The thrust surfaces at the base of these units subsequently became a locus for later extensional shearing during which time $S_{2}$ fabrics were completely overprinted by younger shear fabrics and often retrograde metamorphic assemblages.

The large-scale geometry of the detachment surface prior to disruption by late faulting is almost impossible to ascertain. However, given the high-angle of intersection between the basal contact of this sheet and upright axial planar $S_{5}$ crenulation cleavages, in regions that are known to represent large-scale $D_{5}$ closures, the original geometry of the sheet is interpreted to be flat or gently dipping.

\section{Discussion}

The essence of our conclusions is that the 'foliation antiform' described by previous workers exists, but we find no support in the field for the notion that it shed lower-grade rocks as it developed. The best-preserved highest-grade (eclogite facies) rocks are found in sheets, and these are folded around the 'foliation antiform'. These sheets are found at the highest structural levels, immediately beneath the over-riding serpentinite with its entrained highpressure blocks. This relation is as illustrated in the schematic structural-metamorphic map shown in Fig. 6. Our mapping shows that the 'foliation antiform' is relatively youthful. The eclogites do not occur (as suggested by previous workers) at its deepest structural levels, i.e. fresh eclogite is not found in the core of this structure.

\subsection{The regional anticline}

Aitchison et al. (1995) propose that the coastal range formed as a 'regional anticline'. They envisage a metamorphic core that was shedding lower-grade rocks including the ophiolite nappe and overlying blueschists. The largescale antiforms that can be mapped in the coastal ranges did not form until relatively late in the geological evolution of northwest New Caledonia. However, the antiform is now transected by the uplifted regolith, and there is no evidence as to its previous geomorphological expression, even though, based on its size, this must have been considerable. In terms of the early history there is no evidence that supports the existence of a regional domal culmination that formed during the exhumation history of the highpressure rocks.

The concept of an 'anticlinal range' (Lillie, 1975; Clarke et al., 1997) is itself misleading. The coastal ranges are defined by uplifted blocks, capped by the younger (? Miocene) peneplain and flanked by relatively young normal faults (Figs. 5, 7 and 9). These uplifted fault blocks define the active geomorphological features of northeast New Caledonia, not the tight antiformal structures in the folded middle stage shear zones that have been locally observed within these fault blocks.

However, whilst this antiformal structure was not responsible for the morphology of the coastal range, it remains a geologically significant feature. Based on mesoscopic overprinting relationships, the timing of its formation is interpreted to be synchronous with the orogen-scale folding previously described from the Diahot Valley region (Rawling and Lister, 1999a). Mapping of coastal outcrops 
between Colnett and Poindimié confirms this interpretation, as large-scale vergence changes indicate the presence of a large synformal closure (with a faulted out hinge) in the Hienghène region.

A second large-scale antiformal closure can also be identified within older rocks near Poindimié. This eastwest striking structure has been previously described by Maurizot (1984) and is interpreted to have formed during the same orogen-scale folding event described here. A similarly oriented large-scale antiformal structure has also been identified offshore in this region by Lafoy et al. (1996) and may indicate that this period of folding did not only affect the metamorphic belt of northern New Caledonia but that it also downfolded blocks of oceanic crust in the Loyalty Basin.

These orogen-scale folds formed after high pressure metamorphism had taken place, and after the high pressure rocks had been (partially) exhumed by the first major period of extension. They are thus relatively youthful, and had little or nothing to do with the period of the geological history described by Cluzel et al. (1995) and Aitchison et al. (1995). These structures may have affected a thinned continental crust, and thus may have also folded the lithosphere into a sequence of tight antiforms and synforms.

\subsection{Oligocene core complexes?}

Cluzel et al. (1995), Aitchison et al. (1995) and Clarke et al. (1997) propose that late-stage extensional tectonism resulted in the exhumation of Oligocene metamorphic core complexes in northeast New Caledonia. This study does not support this conclusion.

Metamorphic core complexes as reported from Nevada and Arizona, within the Colorado extensional corridor (Davis and Coney, 1979; Coney, 1987; Spencer and Reynolds, 1991; Wernicke, 1992), the Aegean Sea (Lister et al., 1984; Vandenberg and Lister, 1996; Forster and Lister, 1996), or from the Solomon Sea (Hill et al., 1992) are geomorphologically active localities involving the emergence of domal landforms flanked by bowed and/or domed detachment faults. The shape of the gneiss dome that forms the interior zone of a metamorphic core complex is typically also defined by the form of a carapace shear zone (e.g. Davis et al., 1983; Reynolds and Lister, 1990). Ductile flow in the carapace shear zones is kinematically coordinated with brittle movement in later formed detachment faults (cf. Wernicke, 1981; Davis et al., 1983; Wernicke, 1992). The domal culmination that defines a core complex is related in part to footwall uplift as isostatic response to tectonic denudation (Spencer, 1984). In addition, dilation of plutons emplaced as sills within the gneiss dome may play a critical role in determining the shape of the gneiss dome associated with some core complexes (Lister and Baldwin, 1993).

There is no doubt that extensional tectonism played a major role in the exhumation and final exposure of the high-pressure metamorphic rocks now visible at the surface in northeast New Caledonia. However, there are no data that support the idea that metamorphic core complexes were active geomorphological entities at this, or any later time. Even so we cannot exclude the possibility that a carapace shear zone to an antiformal geomorphological culmination may have formed during middle stage extensional tectonism. The presently exposed carapace shear zone is now tightly folded, with antiformal culminations as mapped in the coastal ranges. This present antiformal structure is the result of later imposed crustal shortening, locally in excess of $50-70 \%$.

There is no evidence for the development of detachment faults associated with the formation of the coastal antiform. Normal faults ( \pm associated reactivated or late-stage shear zones) flank the uplifted blocks that define the coastal ranges (with dips that range from 15 to $45^{\circ}$ ). However, these faults are interpreted to be opposite facing, latestage, brittle normal faults of the same generation (Figs. 6 and 11). They do not represent a continuous detachment surface that is folded about the domal/antiformal core.

\subsection{Significance of the serpentinite sheet}

This study suggests the existence of a mappable unit, here loosely referred to as a serpentinite sheet, containing blocks of fine- to coarse-grained, foliated and unfoliated eclogites and blueschists. This boulder mélange is comparable with other occurrences of high-pressure rocks, such as the Franciscan (Berkland et al., 1972), Baja (Sedlock, 1996), and northern Syros, Aegean Sea, Greece (Dixon and Ridley, 1987). As is the case also in the Aegean, in New Caledonia there is a close association with a coherent terrane also metamorphosed under medium to high pressure conditions. The blocks best preserve the oldest part of the metamorphic history, but this history can also be recognised in allochthonous slices in the adjacent coherent high-pressure terrane.

The serpentinite bodies do not appear to have been injected along vertical faults. Their geometry is not consistent with steep, fault-bounded, discrete lenticular bodies. Yet the emplacement of this material has long been considered a result of tectonic injection from depth along steep thrust surfaces (Lillie, 1970; Brothers and Blake, 1973; Lillie, 1975; Black and Brothers, 1977). Previous workers have not identified these serpentinite remnants as being part of a single sheet that originally overlay the rocks of the high-pressure zone.

The serpentinite sheet (and associated boulder mélange) appears to flank the antiformal core defined by the folded middle stage shear zones of northeast New Caledonia. Thus, in contrast to previous workers, we suggest that the best preserved and potentially highest pressure metamorphic rocks occupy the highest structural levels. The serpentinite sheet is in fault contact with underlying schists and gneisses and mafic sheets. It is separated from these rocks by brittle faults and $\left(D_{4}\right)$ ductile shear zones $1-20 \mathrm{~m}$ in thickness. 
Serpentine plus the entrained blocks is locally injected into the underlying rocks during subsequent tight folding $\left(D_{5}\right)$.

\subsection{Well preserved eclogites in the Pam Peninsula}

Clarke et al. (1997) recognised two different types of eclogite in the region, based on petrological differences. Both of these eclogites are from the coherent part of the terrane and Clarke et al. (1997) did not recognise the high-grade blocks from within the serpentinite sheet. In cross sections through the Pam Peninsula region these authors did not include a serpentinite sheet and in fact proposed that the lower-grade rocks of the Diahot Valley region overlay the high-pressure schist belt in the manner of Yokoyama et al. (1986). These previous workers have suggested that both the best-preserved and highest-grade eclogites are exposed within the core of an antiformal structure (Aitchison et al., 1995; Cluzel et al., 1995; Clarke et al., 1997). However, this does not appear to be the case. The well-preserved eclogites are exposed at the highest structural levels, either in the overlying folded ultramafic sheet, or within folded sheets in the zone of mélange that immediately underlies it. These rocks are up to a kilometre higher in the structural section than the retrogressed eclogites deeper in the core of the regional antiform (Fig. 6).

Note that the retrogressed eclogites reveal a similar petrogenesis to those that are well-preserved as blocks in the ultramafic sheet. This is a critical observation because it shows that the rocks of the gneissic core and the overlying serpentinite sheet have undergone a similar metamorphic history and that the core of the structure has not been exhumed from much greater depths (Rawling, 1998).

\subsection{Low-angle isograd surfaces}

An isograd is defined by the onset of metamorphic reactions, and thus by the appearance of specific minerals, mineral parageneses and/or mineral compositions. Thus, an isograd should not be defined by the completion of specific mineral reactions, nor by the disappearance of specific phases related to the degree of pervasiveness of later retrograde (or otherwise overprinting) metamorphic reactions. The complex structure of the high-pressure zone thus makes it unlikely that original isograd surfaces will ever be recognised.

High-pressure metamorphism took place early in the geological history of the rocks of the high-pressure zone. Therefore isograd surfaces will have undergone modification by each and every separate deformation event that has later affected these rocks. Different tectonic units are likely to have experienced different grades of metamorphism and different degrees of later retrogression (from omphacite + garnet eclogite facies assemblages through epidote-garnet-glaucophane-phengite retrograde blueschist assemblages for example). Definition of isograd surfaces must take place in the context of the history of metamorphism, in space, as well as through time.
Yokoyama et al. (1986) suggest that the isograd surfaces dip (uniformly?) at $10^{\circ}$ to the southwest and were produced in single facies series, in " $a$ direct progression from lawsonite-albite-chlorite schist through blueschist facies to the eclogite facies". These conclusions seem unlikely in view of our data (see also Rawling, 1998; Rawling and Lister, 1999a), both in respect to the complex postmetamorphic structural evolution undergone by these rocks, as well as the complex retrograde metamorphism ( \pm metasomatism) to which the rocks have been subjected.

The concept that large 'schuppen' were thrust northeastwards "to form a capping over the high-pressure schists during metamorphism" (Brothers 1974; Yokoyama et al., 1986) could also not be substantiated. Rocks in this zone appear to contain generally steeply dipping fabrics formed by (now tightly folded but once low-angle) middle-stage shear zones, as well as schists and mafic gneisses equivalent to rocks found below the zone of tropical weathering beneath the uplifted Miocene peneplain (e.g. in the Mayavetch Valley).

Some clue as to the nature of the isograd 'surfaces' can be ascertained from Yokoyama et al. (1986, fig. 4). The appearance of omphacite seems to be structurally related to the antiform defined by the folded middle stage shear zones. However, rather than marking the first appearance of omphacite in a prograde sequence, we suggest that the data points may instead reflect first indications of the survival of omphacite through the history of later metamorphism.

On a larger scale, the data presented by Yokoyama et al. (1986, fig. 3) are broadly consistent with an upwards increase in metamorphic grade through a tightly folded middle stage shear zone and its overlying tectonic slices. The present work finds no support for the conclusion that "the isogradic surfaces for epidote and omphacite post-date and cut across a major antiform" or for the conclusion that the isograds "were not flexed by regional folding". In fact the view expressed here is the opposite, concluding that: (1) epidote was introduced as part of a paragenetic sequence during retrograde metamorphism associated with the development of middle stage shear zones; (2) omphacite survives only where later blueschist facies metamorphism ( \pm metasomatism) has not lead to its obliteration; and (3) surfaces defined by change in mineral paragenesis mimic the complex form of the folded middle stage shear zones. Additional variation occurs because of the juxtaposition of different tectonic slices during middle-stage extensional tectonism $\left(D_{4}\right)$. Additional complications have been introduced by the effects of late stage faulting. High-pressure metamorphism had long concluded by the time such movements took place.

Yokoyama et al. (1986) suggest that final cooling and depressurisation took place as the result of "block faulting movements that terminated the metamorphic event". Structural analysis suggests that eclogites of the Pam Peninsula were already substantially uplifted by the time that middle 
stage extensional movements took place, during $D_{4}$. In fact, the survival of relict omphacite in the Pam Peninsula is a direct consequence of the fact that these rocks occupied relatively high structural levels during middle-stage extensional shearing, and thus better preserved the highpressure assemblages generated during the prior overthrust event.

The error of Yokoyama et al. (1986) can be seen in the fact that block faulting has elevated the Miocene peneplain to progressively higher elevations towards the south, but this has not exposed deeper level metamorphic rocks. In contrast, the geometry of the folded middle stage shear zones preserved within these fault blocks allows a glimpse into deeper structural levels, where a more prolonged history of metamorphism has allowed more complete obliteration of the earlier formed metamorphic assemblages.

The identification of lawsonite within the Amoss Ridge region of the Pam Peninsula by Yokoyama et al. (1986) resulted in their interpretation that the shallowly dipping lawsonite isograd clipped the top of the ridge. However, this lawsonite-bearing outlier more likely represents a fault-bounded klippen separated from the underlying retrogressed eclogite by a low angle brittle normal fault or narrow ductile shear zone that was not identified by the previous workers.

\subsection{The geological terranes of New Caledonia}

A geological terrane is defined as "a fault-bounded body of rock of regional extent, characterised by a geological history different from that of contiguous terranes" (Jackson, 1997). Detailed structural and petrological investigation of the high-pressure Pam-Panié region and the adjacent Diahot Valley region (Rawling and Lister, 1999a) indicates that there is no sound basis for dividing these rocks into separate terranes as proposed by Cluzel et al. (1995). These rocks have undergone a very similar structural and metamorphic evolution. Indeed most of the major deformation events and some metamorphic crystallisation events are correlatable across much of the belt (Fig. 6).

The rocks of the Pam-Panié region were metamorphosed at higher grade but this merely represents exposure of deeper levels of the same metamorphic pile in this part of the high-pressure schist belt. The rocks of both the PamPanié region and the Diahot Valley region show evidence for the development of a strongly developed, locally differentiated, crenulation cleavage associated with highpressure mineralogies. Both regions show evidence for an early period of extensional tectonism resulting in significant exhumation of the belt. Both regions were subsequently folded into regional scale mega-folds that were then disrupted by brittle faulting late in the tectonic evolution. There is also evidence for relatively high-temperature but presumably short-lived thermal events (preserving HP/LT assemblages) that immediately predate the two major extensional events in both regions.

\section{Conclusions}

The following conclusions can be drawn as a result of this study:

1. The high pressure metamorphic tectonites of northeast New Caledonia were once overlain by a gently inclined mafic and ultramafic sheet. The remnants of this ophiolite (?) are now preserved as serpentinite bodies, above now folded and faulted low-angle thrusts and/or extensional detachment-related shear zones or faults, or encased in tight synforms produced during late-stage renewed compression of the orogenic belt.

2. The serpentinite bodies have entrained within them blocks of various types forming a boulder mélange. These include well-preserved high pressure mafic eclogites. These are only weakly deformed, and little affected by later events. Since they were protected from retrogression, these are the best preserved high-pressure rocks in New Caledonia.

3. Several generations of shear zones have been recognised. The earliest shear zones appear to be associated with overthrusting of the ultramafic sheet. Middle stage shear zones appear to be associated with exhumation of the high-pressure rocks, as the result of extensional tectonism. These shear zones were folded (on an orogen-scale) when the extended crust was subsequently folded as the result of renewed compression. Late stage shear zones formed when the orogen was once again thrown into extension.

4. The last generation of shear zones is associated with orogen-scale high-angle normal faults, and these juxtapose the metamorphic zones recognised throughout the high pressure belt of New Caledonia. The classic lowangle metamorphic isograds discussed extensively in the literature do not exist. The geometry of metamorphic grade changes is entirely controlled by this late stage of faulting and shearing.

5. Relatively youthful normal faults caused late blockfaulting, uplifted and offset the regional peneplain and produced the present geomorphology.

6. The foliation antiform recognised by previous authors in the uplifted horst block of northeast New Caledonia is not a structure that has any resemblance to a metamorphic core complex, as previously reported. It was formed when renewed crustal shortening was initiated, after the first major epoch of extensional tectonism partially exhumed the high-pressure metamorphic rocks from beneath the overlying ultramafic sheet. This produced an orogen-scale antiform that can be traced throughout the high-pressure belt, folding all previously formed lithologies, fabrics and shear zones.

7. There is no eclogite core to the foliation antiform of the coastal high-pressure belt, as proposed by Cluzel et al. (1995); Clarke et al. (1997). Whilst there is evidence to suggest the rocks of the core region reached eclogite 
facies, it is misleading to refer to this as an eclogite core as the best preserved eclogites occur higher in the structural pile.

8. The high-pressure Pam-Panié region and the adjacent Diahot Valley region do not represent separate terranes as proposed by Cluzel et al. (1995). The rocks in each of these regions have undergone a very similar structural and metamorphic evolution at different levels in the metamorphic pile.

\section{Acknowledgements}

This research was supported by an Australian Research Council grant to study "Continental Extension Tectonics". Suzanne Baldwin, Caroline Venn and Sandra Occhipinti are thanked for stimulating discussions and their efforts in this collaborative project between the Monash group and the University of Arizona, Tucson, USA. The manuscript has been substantially improved thanks to the comments of M. Clarke Blake Jr., Richard Norris and an anonymous reviewer. We gratefully acknowledge the support of the Bureau de Recherches Géologique et Mineres and thank in particular Jean-Jacques Espirat, Pierre Maurizot and Jacques Leguere for their help, suggestions and interest in the project. We would also like to sincerely thank Hippolite Hounda, the petit chief of Tribu de Colnett, for his unsurpassed hospitality. Some of the work reported here was conducted under the auspices of the Australian Geodynamic Cooperative Research Centre.

\section{References}

Aitchison, J., Clarke, G.L., Meffre, S., Cluzel, D., 1995. Eocene arccontinent collision in New Caledonia and implications for regional Southwest Pacific tectonic evolution. Geology 23, 161-164.

Avias, J., 1967. Overthrust structure of the main ultrabasic New Caledonian massives. Tectonophysics 4, 531-541.

Baldwin, S.L., Rawling, T.J., Fitzgerald, P.G., 1998. Burial, Metamorphism, and Exhumation of the High P/T Terrane, New Caledonia: Implications for mid-Tertiary Plate Boundary Processes in the SW Pacific, EOS, Transactions of the American Geophysical Union, 79(45), F889.

Bell, T.H., Brothers, R.N., 1985. Development of P-T prograde and P-retrograde, T-prograde isogradic surfaces during blueschist to eclogite regional deformation/metamorphism in New Caledonia, as indicated by progressively developed porphyroblast microstructures. Journal of Metamorphic Geology 3, 59-78.

Berkland, J.O., Raymond, L.A., Kramer, J.C., Moores, E.M., O’Day, M., 1972. What is Franciscan? The American Association of Petroleum Geologists Bulletin 56, 2295-2302.

Black, P.M., Brothers, R.N., 1977. Blueschist ophiolites in the mélange zone, northern New Caledonia. Contributions to Mineralogy and Petrology 65, 69-78.

Black, P.M., Brothers, R.N., Yokoyama, K., 1988. Mineral paragenesis in eclogite facies meta-acidites in northern New Caledonia. In: Smith, D.C. (Ed.). Eclogites and Eclogite Facies Rocks. Developments in Petrology 12Elsevier, Amsterdam, pp. 271-289.

Black, P.M., Maurizot, P., Ghent, E.D., Stout, M.Z., 1993. Mg-Fe carpholites from aluminous schists in the Diahot region and implications for preservation of high-pressure/low-temperature schists, northern New Caledonia. Journal of Metamorphic Geology 11, 455-460.

Briggs, R.M., 1975. Structure, metamorphism and mineral deposits in the Diahot region, northern New Caledonia. Ph.D. thesis, University of Auckland.

Briggs, R.M., Lillie, A.R., Brothers, R.N., 1978. Structure and highpressure metamorphism in the Diahot region, northern New Caledonia. Bulletin du Bureau de Recherches Géologiques et Minières Section 4, 171-189.

Brothers, R.N., 1974. High-pressure schists in northern New Caledonia. Contributions to Mineralogy and Petrology 46, 109-127.

Brothers, R.N., 1985. Regional mid-Tertiary blueschist-eclogite metamorphism in northern New Caledonia. Géologie de la France 1985, 37-44.

Brothers, R.N., Blake Jr, M.C., 1973. Tertiary plate tectonics and highpressure metamorphism in New Caledonia. Tectonophysics 17, 337358

Clarke, G.L., Aitchison, J.C., Cluzel, D., 1997. Eclogites and blueschists of the Pam Peninsula, NE New Caledonia; a reappraisal. Journal of Petrology 38, 843-876.

Cluzel, D., 1998. The post-obduction flysch of nepoui, a transported basin-inference on the age and setting of the Tertiary obduction in New Caledonia (Southwest Pacific). Comptes Rendus de l'Academie des Sciences Serie II Fascicule A-Sciences de la Terre et des Planetes 327, 419-424.

Cluzel, D., Aitchison, J.C., Clarke, G., Meffre, S., Picard, C., 1995. Dénudation tectonique du complexe à noyau métamorphique de haute pression Tertiaire du Nord de la Nouvelle-Calédonie (Pacifique, France) données cinématiques. Comptes Rendus de l'Academie des Sciences, Serie II 321, 57-64.

Cluzel, D., Chiron, D., Courme, M.D., 1998. Upper Eocene unconformity and pre-obduction events in New Caledonia. Comptes Rendus de l'Academie des Sciences Serie II Fascicule A-Sciences de la Terre et des Planetes 327, 485-491.

Collot, J.Y., Malahoff, A., Recy, J., Latham, G., Missegue, F., 1987. Overthrust emplacement of New Caledonia ophiolite; geophysical evidence. Tectonics 6, 215-232.

Coney, P.J., 1987. The regional tectonic setting and possible causes of Cenozoic extension in the North American Cordillera. In: Coward, M.P., Dewey, J.F., Hancock, P.L. (Eds.), Continental Extensional Tectonics. Geological Society Special Publication 28, pp. 77-186.

Davis, G.H., Coney, P.J., 1979. Geologic development of the Cordilleran metamorphic core complexes. Geology 7, 120-124.

Davis, G.H., Lister, G.S., Reynolds, S.J., 1983. Interpretation of Cordilleran core complexes as evolving crustal shear zones in an extending orogen. The Geological Society of America, Rocky Mountain Section, 36th annual meeting; Cordilleran Section, 79th annual meeting, Geological Society of America (GSA), Boulder, CO, USA, 15, p. 311.

Dixon, J.E., Ridley, J., 1987. Syros; Chemical transport in metasomatic processes. In: Helgeson, H.C. (Ed.). NATO ASI Series. Series C: Mathematical and Physical Sciences 218, pp. 489-518.

Forster, M.A., Lister, G.S., 1996. Separate episodes of eclogite and blueschist metamorphism in the Ios metamorphic core complex, Cyclades, Greece. Evolution of metamorphic belts, Bundoora, Australia, Dec. 16-17. Geological Society of Australia Abstracts Series 42, 20-21.

Hill, E.J., Baldwin, S.L., Lister, G.S., 1992. Unroofing of active metamorphic core complexes in the D'Entrecasteaux Islands, Papua New Guinea. Geology 20, 907-910.

Jackson, J.A., 1997. Glossary of Geology. American Geological Institute, Alexandria.

Lafoy, Y., Missegue, F., Cluzel, D., Le Suave, R., 1996. The Loyalty-New Hebrides arc collision; effects on the Loyalty ridge and basin system, Southwest Pacific (first results of the ZoNeCo Programme). In: Auzende, J.-M., Collot, J.-Y. (Eds.), Seafloor Mapping in the West, Southwest and South Pacific; Results and Applications. Marine Geophysical Researches 18, pp. 337-356. 
Lillie, A.R., 1970. The structural geology of lawsonite and glaucophane schists of the Ouegoa District, New Caledonia. New Zealand Journal of Geology and Geophysics 13, 72-116.

Lillie, A.R., 1975. Structures in the lawsonite-glaucophane schists of New Caledonia. Geological Magazine 112, 225-240.

Lister, G.S., Baldwin, S.L., 1993. Plutonism and the origin of metamorphic core complexes. Geology 21, 607-610.

Lister, G.S., Banga, G., Feenstra, A., 1984. Metamorphic core complexes of Cordilleran type in the Cyclades, Aegean Sea, Greece. Geology 12, 221-225.

Maurizot, P., 1984. Carte géologique à l'échelle du 1/50 000 et Notice explicative su la feuille-Touho-Poindimié. Bureau de Recherches Géologiques et Minières, 1-43.

Maurizot, P., Eberle, J.-M., Habault, C., Tessarollo, C., 1989. Carte géologique à l'échelle du 1/50 000 et Notice explicative su la feuille-Pam-Ouégoa. Bureau de Recherches Géologiques et Minières, $1-81$.

Rawling, T.J., 1998. Oscillating orogenesis and exhumation of highpressure rocks in New Caledonia, SW Pacific. Ph.D. thesis, Monash University.

Rawling, T.J., Lister, G.S., 1999. Oscillating modes of orogeny in the Southwest Pacific and the tectonic evolution of New Caledonia. In: Ring, U., Brandon, M.T., Lister, G.S., Willett, S.D. (Eds.), Exhumation Processes: Normal Faulting, Ductile Flow, and Erosion. Geological Society of London Special Publication 154, pp. 101-112.

Rawling, T.J., Lister, G.S., 1999. The high-pressure sole of the New Caledonia ophiolite belt. Specialist Group for Tectonics and Structural Geology's Last Conference for the Millennium, Halls Gap, February 14-19, Geological Society of Australia Abstracts Series 53.

Rawling, T.J., Streets, C.J., Lister, G.S., 1994. The structural evolution and tectonic significance of the mid-Tertiary blueschist-eclogite belt, Northern New Caledonia. Geological Society of Australia Abstracts Series 37, 250-251.

Reynolds, S.J., Lister, G.S., 1990. Folding of mylonitic zones in Cordilleran metamorphic core complexes; evidence from near the mylonitic front. Geology 18, 216-219.
Sedlock, R.L., 1996. Syn-subduction forearc extension and blueschist exhumation in Baja California, Mexico. In: Bebout, G.E., Scholl, D.W., Kirby, S.H., Platt, J.P. (Eds.), Subduction Top to Bottom. Geophysical Monograph 96, pp. 155-162.

Spencer, J.E., 1984. Role of tectonic denudation in warping and uplift of low-angle normal faults. Geology 12, 95-98.

Spencer, J.E., Reynolds, S.J., 1991. Tectonics of mid-Tertiary extension along a transect through west central Arizona. Tectonics 10, 10241221.

Streets, C.J., 1995. The tectonic evolution of the high pressure schist belt northern New Caledonia: implications of a detailed study of the high pressure metamorphic tectonites of northwest Yambé and the Amoss, Mayavetch and Ouébato River Valleys. M.Sc. thesis, Monash University.

Streets, C.J., Rawling, T.J., Lister, G.S., 1994. Structure and metamorphism in the Koumac-Balade high pressure schist belt, northern New Caledonia, Deformation processes in the Earth; from microcracks to mountain belts; field conference, Jindabyne, N.S.W., Australia, Feb. 6-11. Geological Society of Australia Abstracts Series 36, 160-161.

Stewart, I.S., Hancock, P.L., 1991. Scales of structural heterogeneity within neotectonic normal fault zones in the Aegean region. Journal of Structural Geology 13, 191-204.

Vandenberg, L.C., Lister, G.S., 1996. Structural analysis of basement tectonites from the Aegean metamorphic core complex of Ios, Cyclades, Greece. Journal of Structural Geology 18, 1437-1454.

Wernicke, B., 1981. Low-angle normal faults in the Basin and Range Province; nappe tectonics in an extending orogen. Nature 291, 645-648.

Wernicke, B., 1992. Cenozoic extensional tectonics of the U.S. Cordillera. In: Burchfiel, B.C., Lipman, P.W., Zoback, M.L. (Eds.). The Cordilleran Orogen; Conterminous U.S., The Geology of North America, G-3, pp. 553-581.

Yokoyama, K., Brothers, R.N., Black, P.M., 1986. Regional eclogite facies in the high-pressure metamorphic belt of New Caledonia. In: Evans, B.W., Brown, E.H. (Eds.), Blueschists and Eclogites. MemoirGeological Society of America 164, pp. 407-423. 